\title{
Community Forests Ensuring Local Governance and Livelihood: A Case Study in Sunwal VDC, Nawalparasi, Nepal
}

\author{
Devi Prasad Paudel \\ Lecturer (Geography) \\ Butwal Multiple Campus, Butwal
}

\begin{abstract}
This paper analyses local governance in forest resource management through people's participation and the ways it relates to the contribution in securing livelihood. This case study was conducted in Sunwal VDC of Western Tarai, Nepal, and information was collected through direct observation, household survey, key informant interview, focus group discussion and analysis of secondary information. It discusses a few examples of how the community forestry programme can be used as a means to promote participation of the women, the poor, disadvantaged and marginalized group in forest resource management, as well as enhancing livelihood and improving the forest resource management in their locality. It is found that though the community forestry programme has positive impacts, it faces several constraints and challenges. The results of the case study clearly indicate that community forestry processes must address the political, economic and social needs of the forest users, and also provide a neutral platform on which the poor and disadvantaged group can express their voices.
\end{abstract}

Key words: Community Forestry, Community Forest Users Groups, Livelihoods, Participation, Sustainable Development, Local Governance.

\section{Introduction}

Participation of local people in development activities to achieve sustainable development and enhance their livelihood has been a core concept in recent development discourses (Agarwal, 2001). Acquiring social justice needs to the distribution of roles and resources among members of a community in terms of social, political and economic decision making (Jordan, 1998). Therefore, there has been a recent trend that all development policies should include a participatory component. In terms of the policy contexts, active participation of poor, ethnic groups and disadvantaged groups are sought, particularly in respect of local actions such as local governance in natural resource management and livelihood outcomes (Agarwal, 2001). 
The concept of participation by local people in Nepal's forest management was officially initiated in the early 1950s, but it only gained momentum in the early 1970s due to a shift in development thinking and practice (Bartlett and Malla, 1992). The 1970s is seen as a 'push decade' for community forestry in Nepal; the push coming from external agencies' interests in being involved in the forestry sector as well as with needs identified by groups within Nepal (Hobley and Malla, 1996). The 1980s was a period of experimentation with different forms of community forestry practices which led to the development of a 20-year Master Plan for the Forestry Sector (MPFS) in 1989. A new political era for Nepal began at the beginning of the 1990s and, consequently, a new era for the forest sector as well. The role of users' interest in resource management and utilization was realized (Hobley and Malla, 1996). Local people through Community Forest User Groups (CFUGs) are involved in managing forest areas in order to fulfill their needs for forest products and, indirectly, to enhance the conservation of soil and water, whilst contributing to improve the environment (Yadav, 2004).

In the management regimes of forest resource in Nepal, the national forest is divided into five types-the government management forest, leasehold forest, collaborative forest, community forest and, protected area management. Community forests therefore, are national forests that have been handed over to forest user groups (FUGs) for development, conservation and utilization for the collective benefit of the community. In the community forestry programme certain section of the national forest is handed over to the local community which has been using the forest traditionally and has interest to manage it. The District Forest Office identifies the users of forest handed over to the local community and support to prepare the constitutions and the operational plan of the community forest management. Based on the provision included in constitutions the group is mobilized based on the approved operational plan.

Approximately, there are 14,500 community Forest User Groups (CFUGs), benefiting over 1.66 million households, which is about 40 percent of Nepal's total households and which are managing around 1.24 million hectares of forest (34.9\% of the potential community forest area) in Nepal (DoF, 2010).

Indeed, in the context of natural resource management, devolving greater power to village communities is now widely recognized as an institutional imperative by governments, international agencies and NGOs. Moreover, rural community forestry groups represent one of the most widespread and rapidly expanding attempts at participatory development (Malla, 2001), which aims to achieve equity and justice in society. As almost 86 percent of the total population resides in rural areas in Nepal, forest is the main source of energy for maintaining the rural livelihoods. Rural people have been dependent on the forest from ancient times for firewood, timber, grass, thatch grass, agricultural tools and other domesticated needs and for non timber forest products (NTFPs) including medicinal herbs. These products thus have become an integral part of rural life. The forest can supply the villages' short-term and long-term needs including material and cash income. Moreover, forest is not only essential for people but also for both wild and domestic animals. Livestock is part of rural livelihood and is mostly dependent on the forest for fodder and grazing. Forest also plays vital role in conserving water resources 
of the rural areas and protect fertile soils. In rural areas, people depend on natural springs for drinking water and small irrigation system has been generated as well from the same source of water. In this context, this paper attempts to analyse the role of community forest in ensuring local governance and livelihood in Sunwal VDC of Nawalparasi District.

\section{Conceptual Framework}

Figure 2.1 is a conceptual framework indicating that forest users living around the forest and have primary rights to use forest products. The main elements of community forest such as local governance and livelihood outcomes are linked with one another. The concept of community forestry which emerged in these circumstances of community livelihood suggests that users are organized in Community Forest User Groups (CFUGs) that allow them to benefit from the forest products and funds for enhancing their livelihood and this will be an incentive for their participation in forest management. Forest management requires inputs, which depend on the interests and the commitment of the users. Intensive management of the forest produces outcomes that are incentives for FUGs.

Figure 2.1: Conceptual framework on resource Management and Livelihood Outcomes through community forestry

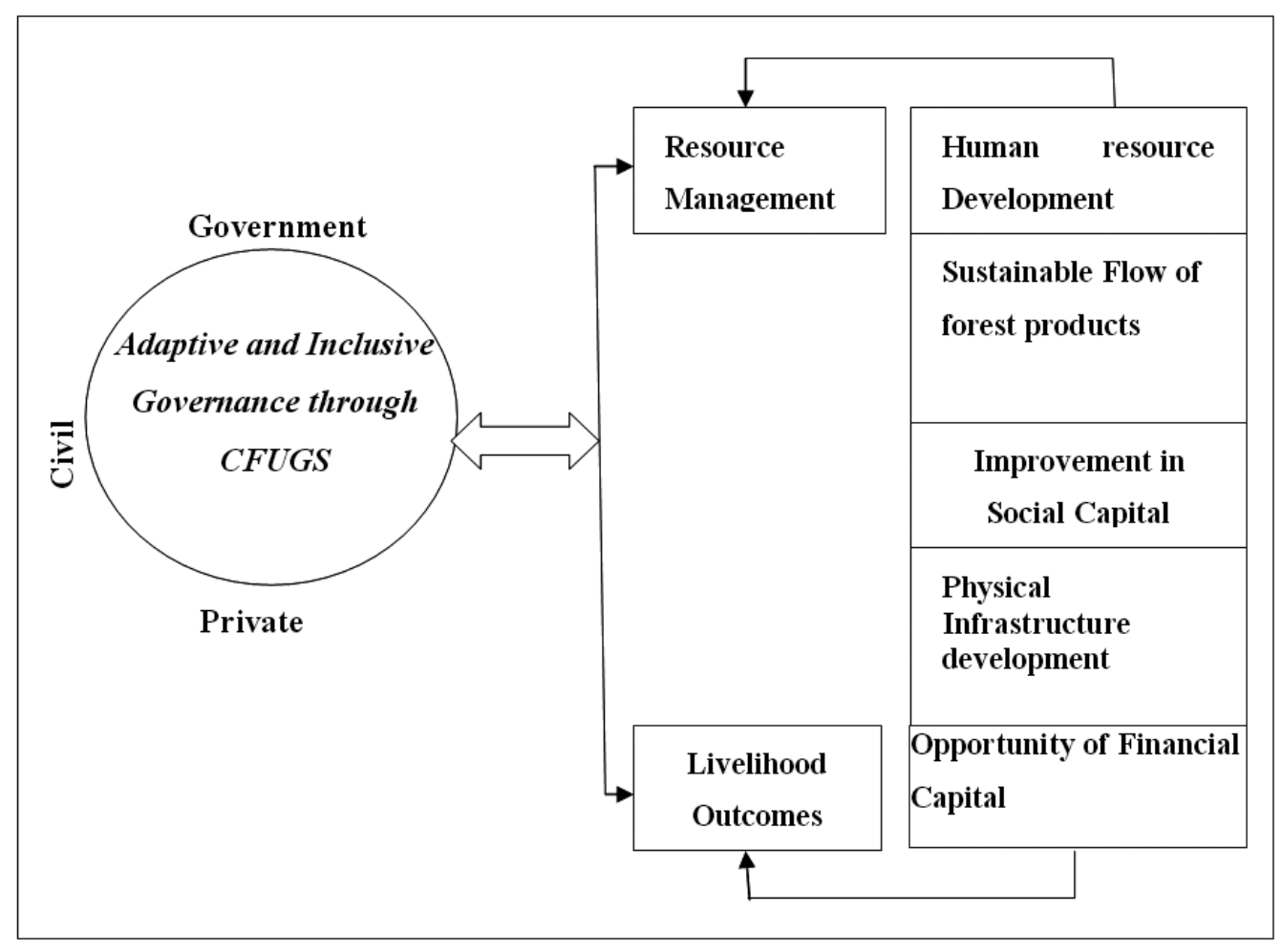




\section{The Study Area, Data and Methods}

Both primary and secondary sources were used to obtain data and information for this study. The primary data was gathered by using different methods, such as field observation, household survey, focus group discussions (FGDs) and key informant interview. Two Community Forest User Groups (CFUGs) i.e. Bisasaya and Sunwal Adarsha Community Forest User Groups were selected purposively, aassuming that most of the user groups residing in areas accessible by roads were more commercial and dynamic than those in remote areas of the district. The selected user groups represented accessible areas located near the northern part of the Highway. Household survey was carried out to collect data and information about socio-demographic characteristics of CFUGs members, forest product use pattern and involvement in FUG activities. Observation protocol was used to supplement the information derived from household survey, focus group discussion and key informant interview from which information regarding the participation of members in meeting particularly of poor and ethnic group, behavior of executive member towards other users were observed. Two focus group discussions were organized one from each CFUG on two specific issues. One discussion focused on the issue of benefit sharing from the community forest, whilst the other was concentrated on the issue of participation of the poor and ethnic group in decision making process. Altogether, ten key informants were interviewed, five individuals from each group to obtain the information regarding history of community forestry in the district, impacts on conservation and livelihood and problems and prospects of community forest. Other Key informants interviwed were District Forest Officer, local school teachers, members of the local NGOs working in forestry sector.

Secondary sources were also used to obtain relevant information. The existing literature on forest resource use and management, policy documents related to forest and land use, and field reports on rural livelihoods, VDC and DDC profile were important sources of information. Information obtained by reviewing the minutes, constitutions and operational plans of the FUG was particularly useful to cross check the information obtained through field discussions.

\section{Results and Discussions}

\subsection{Socio-demographic characteristics of Community Forest User Groups}

Socio-demographic indicators are important components of understanding resource management, livelihood impacts and the opportunities and constraints faced by the CFUGs. It is helpful to understand the changing relationship between local people and community forest in the study area. The ethnic and caste composition reveals the socio-cultural mirror of the study area, where 48 CFUGs household have been taken as a sample. The following table has presented the membership by caste and ethnicity.

Table-1 Caste and Ethnic composition of CFUGs

\begin{tabular}{lll}
\hline Caste and Ethnic Group & Total & Percent \\
\hline Janajati(Magar, Gurung, Kumal) & 17 & 35.41 \\
Brahmin/Chhetri & 16 & 33.33 \\
Madeshi/Tharu & 12 & 25.00 \\
Dalit & 3 & 6.25 \\
\hline Total & 48 & 100 \\
\hline
\end{tabular}

Field Survey, 2009 
The above table shows that ethnic group seems to be more active to participate in the management of community forest and they represent 36.41 percent as the CFUG members. Magar and Gurung are dominant ethnic groups of the study area. The Brahmin and Chhetri are the major caste groups who have played the crucial role to protect and manage the forest and they comprise 33.33 percent and that is followed by Madeshi, Tharu and Dalits,

\subsubsection{Energy Consumption}

Forests have traditionally been the major energy source in Nepal. Recently, the use of improved cooking stoves (ICS), LP Gas, Bio Gas, Agricultural residues, solar energy etc. as energy is increasing day by day in the areas of Nepal. But in the study area the members of CFUGs use different types of fuel as energy such as firewood, biogas, LP gas, dry dung (Guitha) etc. The status of Energy (fuel) has been rpresented in the following table.

Table-2 Energy consumption

\begin{tabular}{lcc}
\hline Types of energy & No of household & Percentage \\
\hline Firewood & 39 & 81.25 \\
Bio gas/Firewood & 2 & 4.16 \\
LP gas/Firewood & 2 & 4.16 \\
Others(Dry cowdung) & 5 & 10.41 \\
\hline Total & 48 & 100 \\
\hline
\end{tabular}

Field Survey, 2009

The table 2 reveals that out of the total sample household 39 sample household $(81.25$ percent) use firewood for cooking. Similarly, Bio-gas, LP gas and animal dry dung cake are also found used as energy source by some households though its percent is nominal. It indicates that like other rural areas of Nepal the users of the study area are still mostly dependent on firewood as everyday source of energy.

\subsubsection{Agriculture Land}

Agricultural land and forest land are interrelated for the livelihoods of rural people. The sample household of CFUGs of Sunwal, there is different pattern of distribution of the landholding size where 36 household have own land and 6 households have no land to cultivate the crops. They have only one house for shelter. Similarly, 6 households do work on rented land for intensive farming. Different categories of landholding size of the sample household are shown in the following table.

Table-3: Land holding size in Hectare

\begin{tabular}{lllc}
\hline Land holding size & No of Hh (own land) & No of Hh (rented land) & Total \\
\hline More than 0.65 & 8 & - & 8 \\
$0.33-0.65$ & 10 & 2 & 12 \\
$0.16-0.33$ & 6 & 4 & 10 \\
Less than 0.16 & 12 & - & 12 \\
Landless & 6 & - & 6 \\
\hline Total & 42 & 6 & 48 \\
\hline
\end{tabular}

Field Survey, 2009 
Table 3 shows that of the total households about one-fourth households have no land to produce crops. It indicates that their livelihood is dependent on forest and agriculture labour. Approximatly 38 percent households have marginal land for agriculture production, however it is not sufficient to sustain their basic food requirements. Only 38 percent households have an area of agricluture land that may support to sustain their livelihoods if land is properly managed. All the households own all or some of livestock like cow, bull, buffalo, goat, and fowls such as duck, chicken etc for which they mostly rely on forest resources. It indicates that as there is no enough land among the households, they depend on forest products to fulfill their basic needs.

\subsection{Governance of community forest user group}

The Community Forest User Group (CFUG) has been a major institution in decisions about the use and management of the forest resources at the village level. According to the FUG constitution, at least one member from each household must come together once or twice a year to discuss matters related to forest resource management and other aspects of development of their village. It accommodates the diverse interests and needs of the users and organizes development activities such as construction of irrigation channels, drinking water facilities, development of road facilities and provides financial support to schools. Almost all members contribute to these activities voluntarily. There are no other organizations at the village level that provide opportunities for discussions about issues of concern to all people (FUG leader personal communication 2009). In this sense, the FUG is a strong instrument of governance at the local level in that it makes people think about and discuss their resources amongst themselves. In some cases, FUGs seem to be more effective than the local government institution (VDC) in delivering development activities at the village level (FUG chairman, personal communication 2009); a similar conclusion has been drawn from other studies of FUGs (FECOFUN 2000).

\subsubsection{Women participation}

Women are the main beneficiaries sought by the community forestry policy. Participation of women in community forest management in the village has increased due to a change in perceptions about the capacity of women to make decisions related to the village as well as their family concerns. The community forestry process in the case study village is considered to be the catalyst that helped to initiate other groups and cooperatives in the area managed primarily by women. Information provided by women participant during the focus group discussion indicates that community forestry has an important catalytic role in bringing women out of the domestic domain. Women are encouraged to take part in community forestry activities by realizing that their contributions to forest management and conservation are important. This is also reflected in the FUG constitution for the village, which has a compulsory provision that at least a third of the committee members should be the women. The contribution of women in protecting the forest in this village is therefore significant. In a focus group discussion, a women member expressed her views about women's role in forest management as follows:

Few years ago, in the dry summer season, there was an incidence of fire in the forest. The fire became more and more out of control. Unfortunately, that day most of the male of the village had gone out for funeral leaving the women and children behind. As soon as we saw the fire in the forest, all the women in the village went to the forest to put out the fire. Many of us carried 
our children with us. After several hours of hard work, we eventually managed to control the fire. It was really a great contribution we made. (Focus Group Discussion 2009)

\subsubsection{Participation of poor and ethnic group}

Ethnic communities seem reasonably happy as their interests are addressed by involving them into CFUGs. Now, they do take part in the meetings and assemblies related to forest management as other caste group. Typical of the way users from ethnic group expressed their feelings as:

We attend the meetings and assemblies related to forest management. We send our children when we are busy. In assembly, several issues are discussed like how to protect forest, how and when to distribute the forest products. We are getting benefit from forest. We get grasses for two months in a year and some firewood. We know all the committee members discuss with them. We are happy that we are being included in social activities as other caste group in our village (Focus Group Discussion 2009).

The community forest user committee organizes various programmes, such as street drama, to raise the awareness of forest users about their rights and responsibilities to use and manage forest resources, and discussion about village activities to be carried out. The users from ethnic community actively take part and are able to play their role in all activities. They participate actively as a member to maintain the constitutional provision of the FUG and implementation of activities assigned by the general assembly of the forest users. In a discussion about their inclusion in leadership and in the use and management of forest resources, they explained that they are gradually being involved than before as other caste group.

\subsubsection{Improvements to the degraded resource base}

According to the forest users, the forest of their village was gradually denuded before it was handed over to them as a community forest. After taking management responsibility, the local users conserved trees and imposed a complete restriction on use for five years. Rules and regulations were established to protect the forest by the users themselves with the assistance of the District Forest Office (Old village member communication 2009). All the users, including women, ethnic groups, Dalits and poor, were involved in the decision making process which was aimed at reviving their local forest. After six to seven years of management by the local community, the formerly denuded area is now full of trees and other vegetations and has started to fulfill the needs of local people to some extent.

\subsection{Livelihood impact of community forestry}

The livelihood impacts of community forestry in the study area are discussed under the following headings:

\subsubsection{Human resource (capital) development in the community}

The development of human resource refers to the capabilities of individuals to secure their well being. The effects of the development of human capital can be cumulative and multiplicative. CFUGs have contributed to improving 'human capital' in a number of ways. Various training and workshops for CFUG members have been provided by the DFO which have improved the skills 
of some CFUG members through nursery foreman training, forest management, record and account keeping, planning and leadership training. Besides that, nine members of each CFUG out of 48 sample household have received skill development training and have been developed as resource persons for their groups.

\subsubsection{Improved and sustainable flow of forest product}

Community forest improves the condition and changes entitlements to use its benefits for fulfilling the community's needs. The legal reform of forest management allows CFUGs to function better, which has improved entitlement and ability to improve the condition of forest resources. This has been achieved through diligent protection of the forests from forest fire, illegal tree felling and unregulated extraction of forest products. The efforts of CFUGs to resolve land disputes with individuals and neighbouring CFUGs are limiting the extent of forest encroachment. Community forest management practices have been enhanced to increase production, maintaining different tree age groups and bio-diversity, including the number and the quality of NTFPs, which directly benefit the local community. In CFUGs, the users are more satisfied with the fact that forest use is now on a sustainable basis both for day-to-day products like fuel wood and also long-term needs such as construction timber. As CFUGs are gaining maturity, they regularize harvesting and the product distribution system in a more effective way.

\subsubsection{Improvement of 'social capital' in the community}

In the case of CFUGs, social capital implies a new social forum for local level development, which is supported to improve social structure and cohesion. The creation and draw-down of social capital benefits depends upon the participation of households and individuals' capacity in local institutions, together with the enhanced knowledge of rights and duties involved in securing a livelihood. The CFUG is adapting the culture of collective action for acquiring benefits. As CFUGs are involved in the production of a variety of products, there is need to develop a network for the generation of other capital. FUGs represent new social capital for local institutions, which is functioning based on community decision-making. CFUGs are focusing beyond the FUG level; this is tole-level development planning, empowering local communities to demand the appropriate services from local government line agencies, VDC and DDC according to local priorities.

\subsubsection{Physical infrastructure development in the community}

CFUG funds are invested in community development activities, which have impacts upon the livelihoods of poor people living in the areas concerned. Generally, CFUGs are more resourceful institutions leading to the development of village level infrastructures or physical capital. In each village, physical facilities tend to be lacking because agencies supporting this aspect do not have a sufficient budget to address all the requirements of the people. In these circumstances, CFUGs are contributing to address the basic needs of villagers as prioritized by them. In the study area, Sunwal Adarsha CFUGs has its own concrete building and enough furniture. Bisasaya CFUGs doesn't have its own building, however, they have fenced most of their community forest area with iron wires. Sunwal CFUGs is found to have a plan to construct one kilometer pitch road between East-West highway and rural area with the help of CFUGs fund. for this. CFUGs have already allocated the budget from the fund. Both CFUGs have played a vital role to construct the toilet and tube well for the poor people with the help of community Fund. 


\subsubsection{Improved opportunities of financial capital as credit}

The provision of financial capital is an outcome (the establishment of micro credit schemes) as is its availability to households. Other requirements of financial capital are for institutional, community development and also for regeneration of forest resources. Both sampled CFUGs have generated funds by selling forest product such as timber, different types of seeds, fruit jam (bell-jam), fodder, firewood, building material etc. Therefore, CFUGs have given contribution to the development of financial capital formation. Both Sunwal Adarsha CFUGs and Bisasaya CFUGs are financially sound. Sunwal Adarsha CFUGs have Rs. 870,566 balance in bank according to CFUGs record of 2007. Similarly, according to Committee record of 2007, Bisasya CFUGs have only Rs. 123,623 bank balance. Both CFUGs have provided loan at $6.5 \%$ interest rate to the poor members of CFUGs in order to create income generating activities (IGA).

The generation of larger funds generally depends on the availability of marketable products in the forest, and an accessible market in which to sell products (e.g. timber and NTFP etc.). CFUGs, which have small resources, have created funds from membership fees on CFUG members and from an external fund generation scheme. External fund generation has been more difficult. Though CFUGs have the opportunity to generate financial assets through effective management of natural resources, the potential for income generation opportunities is not being exploited fully by CFUGs yet. The scheme of savings and credit groups has also played an important role in increasing households' financial assets. However, both CFUGs have moved towards mobilizing their funds for micro-credit, but this is increasing due to the high demand from users.

\section{Constraints and challenges}

Community development concept was initiated during the 1950 s with a perception that it would provide opportunities for better quality of life. In the later decades, it emerged in different forms but the real development requirements in the community are still valid. CFUGs are still facing different types of problems at the local level. This has resulted in the capture of decision making by local elites with the purpose of getting individual benefits. It has always been a challenge to make these organizations more accountable and responsive to poor, disadvantaged groups and women. To strengthen more inclusive process of representation in CFUGs committees to make them more accountable and responsive to forest users has been another important task of CFUGs. In addition to these challenges, control of smuggling of woods and timbers to the bordering areas have been a serious challenge to CFUGs of the study area for sustainable use for the poor and disadvantaged members of the community. CFUG is a natural resource base that provides important inputs for rural livelihoods. Although support for different components of livelihood is provided by line agencies, they are not sufficiently developed to address all the needs and requirements put forth by local groups or institutions. CFUGs, in this sense have been effective in delivering services to the needy society despite many challenges they have been facing.

\section{Conclusions}

CFUGs have been established as new institutions in the community to manage forest, distribute the forest products and deliver the related services to the user members. The institutional capacity of the CFUGs is essential for both the strengthening of group's cohesion and 
management of forest properly. From the field evidence and research experience, it is seen that a capable institution contributed more to the management of community forest because forest management requires more labour inputs to operate different operations in different seasons as planned by the FUGs. All the forest users including women, ethnic group, Dalits and poor have participated in decision making process after the management of community forest was taken over by the local community. The formerly degraded area is now full of trees and other different types of vegetations. CFUGs have been contributing to increase the biodiversity with the control of unregulated exploitation of forest products. Similarly, CFUGs are contributing to enhance different capitals such as financial, human, social, natural and physical capital in the community.

The trend shows the increasing contributions of community forestry in the improvement of the livelihood of disadvantaged households. However, it is essential to ensure the rights of the poor and marginalized section of the community in the constitution and forest operation plans along with national level plans and policies. Mobilization of group fund for improvement of livelihoods of these poor members will be an important area to enhance their ownership and participaton towards community forest. From an institutional perspective, the policy environment for community forestry is favorable. Further decentralization of the forestry sector is envisaged in the interim constitution as well. This will provide an opportunity for local governments and forest user groups to share responsibility and benefits from forests. Community forestry policy has sought to increase the local institutional capacity through formation of user groups (UGs). All these initiatives and actions towards community forest can play a vital role in forest resource management and securing livelihood of the local people.

\section{References}

Agarwal, B. (2001). Participatory exclusions, community forestry, and gender: an analysis for South Asia and a conceptual framework World Development (29): 1623-48

Bartlett, A.G. and Malla, Y.B. (1992) Local forest management and forest policy in Nepal, Journal of World Forest Resource Management (6): 99-116.

DDC (2009), District Profile of Nawalparasi District. Nawalparasi: District Development Committee.

DoF (2010). Community Forest User Groups Database Record. Kathmandu: Department of Forests.

FECOFUN (2000), Community Forestry in Tarai: Principle and Practice. Kathmandu: Federation of Community Forest Users-Nepal.

Hobley, M. and Malla, Y. B. (1996), From Forests to Forestry - The Three Stages of Forestry in Nepal: Privatization, Nationalization and Populism. In M. Hobley (ed.), Participatory Forestry: The Process of Change in India and Nepal, pp. 65-92, London: Overseas Development Institute (ODI).

Jordan, B. (1998), The New Politics of Welfare: Social Justice in a Global Context. London: Sage.

Malla, Y. B. (2001), Changing Policies and the Persistence of Patron-client Relations in Nepal: Stakeholders' Responses to Changes in Forest Policies. Environmental History (6): 287-307.

Yadav, N, P. (2004), Fortest user Groups in Nepal : Impacts on Community Forest Management and Community Development. Unpublished Ph.D. Dissertation. U.K.: The University of Leeds, School of Geography. 